RESEARCH ETHICS

\title{
Can artificial parthenogenesis sidestep ethical piffalls in human therapeutic cloning? An historical perspective
}

\section{H Fangerau}

$J$ Med Ethics 2005;31:733-735. doi: 10.1136/jme.2004.010199

The aim of regenerative medicine is to reconstruct tissue that has been lost or pathologically altered. Therapeutic cloning seems to offer a method of achieving this aim; however, the ethical debate surrounding human therapeutic cloning is highly controversial. Artificial parthenogenesis-obtaining embryos from unfertilised eggs - seems to offer a way to sidestep these ethical piffalls. Jacques Loeb (1859-1924), the founding father of artificial parthogenesis, faced negative public opinion when he published his research in 1899. His research, the public's response to his findings, and his ethical foundations serve as an historical argument both for the communication of science and compromise in biological research.

Correspondence to: Dr H Fangerau, Institute for the History of Medicine, Heinrich-Heine University Düsseldorf,

Universitaetsstrasse 1, 40225 Düsseldorf, Germany; heiner. Fangerau@uni-duesseldorf.de

Received 29 July 2004 In revised form 26 December 2004 Accepted for publication 16 March 2005 S dream of regenerative medicine. Tissues or organs that are pathologically altered are reconstructed with the help of pluripotent stem cells replacing the lost or altered cells. Just as some lizards are capable of regenerating their tail, physicians and researchers hope to be able to regenerate deteriorated or pathologically altered human tissue with the help of stem cells. There are high hopes of pluripotent embryonic stem cells possessing the capability of differentiating into the greatest variety of other cell types, and of "therapeutic cloning", describing the generation of autologous embryonic stem cells through somatic cell nuclear transfer.

Crucial ethical issues in this context are human therapeutic cloning and research with human embryonic stem cells. In these ethical debates it is usually not the aim of regenerative medicine under discussion but the means to achieve this aim. Each method of gaining human embryonic stem cells may have its own ethical implications. However, the basic ontological problem shared by them all is that embryos, from which stem cells derive, could theoretically develop into humans if transferred into a uterus. The embryo's potency results in ethical considerations both of using it for research and destroying it: critics are of the opinion that the embryo's potency forbids research with human embryonic stem cells. ${ }^{1-3}$

Recently, a way of sidestepping the issue of human therapeutic cloning was found. A group of scientists was able to gain embryonic stem cells by parthenogenesis. They were able to isolate stem cell lines from primate embryos tem cell research aims at fulfilling the grown from unfertilised eggs. ${ }^{4}$ In primates, and thus in human beings, parthenotes are unable to grow into viable fetuses, because two gene sets are necessary to produce viable embryos. Consequently, therapeutic cloning for regenerative medicine can be avoided, if scientists can find ways to derive stem cells from human parthenotes. Human parthenotes have already been artificially induced by different means. ${ }^{67}$

Although there may still be objections to stem cell research in general and this method in particular (because people may feel uneasy about producing cells whose status as a life form is ambiguous), the argument that embryos are killed for gaining human embryonic stem cells becomes invalid. Furthermore, for producing genetically compatible material for a patient, parthenogenesis might be a simpler method than therapeutic cloning. ${ }^{8}$ However, as oocytes are used, only women would benefit from embryonic stem cells derived from parthenogenetic eggs.

The reproductive quirk called "parthenogenesis" of some reptiles and lower animals was artificially induced for the first time in sea urchins and reported in 1899 by the GermanAmerican scientist Jacques Loeb (1859-1924). Loeb had been able to achieve embryologic development without fertilisation in sea urchins by putting them into appropriate salt solutions. It is noteworthy that even as early as this 1899 paper he had speculated about the possibility of parthenogenesis in mammals. Ironically, Loeb's research-that today might be considered a way of limiting ethical obstacles to regenerative medicine with human stem cells-met an extremely negative public response at the time.

The aim of this paper is to display the contemporary public reaction to Loeb's entrepreneurial approach from 1899 and to describe his epistemology as well as the ethics guiding his research. This will serve to explain ontological clashes between scientists and the public that can occur within pluralistic societies only presumed to share common norms. ${ }^{10-12}$ Furthermore, the example of Loeb and artificial parthenogenesis in 1899 and 2004 will dismantle some of the mechanisms of solving ethical differences between scientists and society by compromising and transforming research goals without changing the means.

After describing Loeb's contribution to the research field of regeneration the public response to his research and his ethics will be displayed. Finally, the conclusions of this historical example for the understanding of the changed status of artificial parthenogenesis and the role of scientific compromising will be drawn. 


\section{REGENERATION}

Before Loeb started his research with animal life forms, he worked as an assistant to the plant physiologist Julius Sachs in Würzburg. During that time he learnt that plants regenerated organs that did not always resemble the previously existing organ. He wanted to find out whether this phenomenon was also true in animals and whether it was controllable, and in 1890-91 he joined the Naples Zoological Station to do experimental research on regeneration in hydroids. He found that a free floating tubularia stem of a certain length not only produces a new hydrant (body) at its distal end, but also at its proximal end, where one would expect a hydrocaulus (shaft) to develop. Similarly, from isolated fragments of planaria Loeb was able to produce animals with two heads. For these phenomena-the substitution of a lost part with a morphological and physiological differing one-he coined the term heteromorphosis. ${ }^{13}{ }^{14}$

Loeb emigrated to the USA in 1891 where he shifted his focus of interest from the problem of regeneration to experimental embryology. This finally led him to the invention of artificial parthenogesis. Today these two streams of basic research seem to rejoin in current questions of regenerative medicine and stem cell therapy.

After Loeb's death in 1924 the well known biologist Curt Herbst described how exciting Loeb's "Untersuchungen zur physiologischen Morphologie der Thiere" (Loeb's research on organisation, growth, and heteromorphosis) were for the (by that time) young generation of zoologists that had been educated in descriptive morphology. Loeb's works confronted them with new ideas of experimental biology and, according to Herbst, Loeb's research into regeneration "threw light like a bright sunbeam into the darkness of morphology ... which during that time was totally under the spell of phylogenetic research" [author's translation]. ${ }^{15}$

\section{PUBLIC RESPONSE}

The public response to Loeb's experimental research and his findings, especially regarding artificial parthenogenesis, was not as supportive as the scientists' response as described by Herbst-Loeb faced ignorance and criticism.

After his artificial parthenogenesis Loeb became what one might call a "visible scientist". He, as well as his research, appeared in the contemporary media. He saw this as a chance to promote his mechanistic approach to biology, which can be summarised as looking for the physico-chemical basis of all life phenomena and gaining control over them with the help of experiments. He formulated an "engineering ideal in biology" as the science historian Philipp Pauly put it. ${ }^{16}$

Jon Turney examined the reaction to Loeb's artificial parthenogenesis in the popular print media to systematically assess the public reaction to his findings. ${ }^{17}{ }^{18}$ Turney found that the fears at the time were expressed in much the same way that the fears towards modern biological findings and methods are expressed today. A central issue was the idea that biologists were on the verge of "creating life". In the awareness of the popular media Loeb's artificial parthenogenesis was closely connected with this new (and still growing) power of experimental biology. Furthermore, it was connected with this power's innate potential. This notion resulted in some critical comments which can be classified into two categories not always readily distinguishable.

- on the one hand Turney found "expressions of antimechanism, grounded in a spiritual or religious disquiet about the direction biological science was taking";

- on the other hand he found comments in which fears become evident regarding how the results of such research might be used. Turney was able to differentiate two streams of thought: commentators were (1) worried that the new powers acquired by biological research might result in new moral problems and (2) critics feared that the new biology practised by Loeb might undermine traditional moral values.

An illustration from the University of California yearbook (although a caricature made by university students) seems to summarise these ideas. It shows three chimaeras in a cage. Below the cage is a picture of Jacques Loeb. The ensemble was captioned: “This group is entitled 'Genesis.' It effectually refutes the biblical legend of the Garden of Eden, and proves that man is descended from a grain of common salt $(\mathrm{NaCl})$. The figure on the right represents an antediluvian Knockers Club; the central figure is a correct imitation of a prehistoric bat. The sweet-faced picture in the lower foreground is that of Dr Loeb. All the people in the cage call him 'papa,' and he seems to like it...". ${ }^{17}$

\section{LOEB'S ETHICS}

The way critics reacted to Loeb's findings on religious grounds or ethical considerations discloses an ontological clash that Loeb released, perhaps not so much with his research but with the underlying philosophy guiding his research and the ethics involved. His positivistic, radical, mechanistic approach with its ethical implications was probably more disturbing to contemporaries than the research itself: artificial parthenogenesis challenges moral values based on religious feelings, particularly if it is considered as a way of creating life; thus in religious terms "playing God".

For Loeb this was no problem at all. On the contrary, overcoming "metaphysical romance" with the help of science was one of his driving forces. ${ }^{19}$ As early as in 1894 he wrote to the Austrian philosopher and physicist Ernst Mach that for him biology would not become a science until abiogenesis succeeded, ${ }^{20}$ a statement he publicly repeated in his book The Dynamics of Living Matter in 1906. ${ }^{21}$ During the First International Monist Congress in 1911 in Hamburg and in his essay "The Mechanistic Conception of Life", he gave a summarising account of his ethical considerations. ${ }^{22}{ }^{23} \mathrm{He}$ argued that human ethics were as much based on chemical mechanisms as human existence. For Loeb, instincts were the root of human ethics, and these instincts were inheritable in the same way body forms were. People ate, drank, were active, and reproduced, not because they were told to do so by any metaphysical instance but because, machine-like, they were compelled to do so. The same was true for workmanship, a mother's love for her child, sense of community, struggle for justice, and so on. Deviations were caused either by economic or social conditions or by mutations.

As a consequence Loeb did not consider the quest for the physico-chemical basis of life phenomena as hubris or "challenging God". On the contrary, he not only wanted to understand the physico-chemical basis of life but he wanted to control it. Based on his ethics his ideal meant extending that control in social contexts as well. ${ }^{24}$ In Loeb's ideal, after finding the chemical source of human ethics, societies could be freed from the metaphysics hindering pure science and any construction inhibiting the chemical mechanism of human ethics. Thus, the idea of artificial parthenogenesis in human oocytes did not create new ethical problems for Loeb; rather it was the beginning of solving them.

\section{CONCLUSION}

This historical example shows that great differences in the understanding of life may exist between scientists and the public. Current negative reactions to scientific findings, such as the current debate about human stem cell research and therapeutic cloning, arise from these fundamental differences. On the other hand, the example of Loeb indicates that 
researchers do not necessarily perform their research without consideration of its ethical implications-they may just apply different ethical principles from their contemporaries. Of course, Loeb not only faced critical response from the public but also from scientists. Scientists also do not necessarily share common, harmonised values. Too often the existence of diverse moral concepts within societies is neglected. ${ }^{11}{ }^{12}$

The question is how the ontological clash caused by Loeb's artificial parthenogenesis was reconciled within the past 100 years, with the result that it is now not seen as a danger to morality but as a possible way of sidestepping ethical problems surrounding human embryonic stem cell research. Were the scientists of Loeb's kind able to convince their colleagues and the public to reject religious doubts and follow other norms, or did society change? The answer is that the concept behind artificial parthenogenesis was not imposed on the public but negotiated to a consensus: it was harmonised to fit different moral standpoints.

It was not Loeb's research in itself which caused the problem but his articulation of the aims of finding the physico-chemical basis of life and making abiogenesis possible. These claims challenged many members of society at the time (among them, of course, also scientists). Today's scientists understand and communicate the aim of artificial parthenogenesis in a completely different manner. They do not argue on an ontological fundamental basis anymore but offer society a research method less controversial than research with human embryos. They offer this method as an alternative way of making regenerative medicine possible one day. Furthermore, the moral language employed by them is not completely antithetical to that of their contemporaries (as was the case with Loeb).

This shift in the understanding and communication of artificial parthenogenesis makes it appear far less controversial than in Loeb's times. It is promoted as an alternative to human embryonic stem cell research and not as a fundamental solution to the riddle of life, and the problems surrounding stem cells from artificial parthenogenesis (such as the restriction of this method to women, the need for a huge amount of oocytes, and so on) are openly discussed. Moreover, this method is communicated as only one alternative in a whole set of methods for "technically" fixing "the ethical bind" of human embryonic stem cells. ${ }^{25}$

Bearing in mind that scientists are embedded in a collective of colleagues as well as in society it becomes clear that they have to argue their research goals in both directions and that during these arguments transformations occur. ${ }^{26}{ }^{27}$ This general process in the case of artificial parthenogenesis gradually transformed its connotations. The result of this transformation was a compromise between scientists and the public. At least the controversy on the epistemological status of artificial parthenogenesis could be settled for some time: scientists left the Loebian standpoint of aiming at abiogenesis, whereas society agreed to the usefulness of this research. The compromise of interpreting artificial parthenogenesis not as a fundamental shift in the understanding of life but as a technical trick of inducing cleavage far from abiogenesis was found. The orientation towards regenerative medicine in the context of stem cell research gives this method a new shift and a new right to exist. (However, a new controversy on the ontological status of the life forms created by artificial parthenogenesis is ahead.)

I would argue that this historical example is an argument for scientists not to pursue their research without reference to public or private interests. The diversity in opinion concerning their research may be used to reconcile research goals for the benefit of both sides. This again may lead to a theoretical diversity that in itself may open the mind for new applications of research findings within other contexts. On a more practical level compromising is useful for scientists, because answering public demands secures the public financial support for scientists. Scientific compromising in itself however is not ethically unproblematic-for example, if the postponement of scientific findings results in the death of people that otherwise could have been saved. Nevertheless, in the case of stem cell research scientific compromising could be considered as a source of creativity. ${ }^{25} 28$

In democratic societies research programmes are usually (ideally) embedded into society's needs and demands, and so there is always the hope that a compromise is found between the differing views of scientists and the public. In the case of artificial parthenogenesis it can be seen how a former morally problematic research programme is now being discussed as a solution for ethical pitfalls. The example shows that in the case of ontological clashes finding a consensus is possible, not only between scientists' research goals and society's fundamental values but also within the fundamental values of a society itself.

\section{REFERENCES}

1 Holm S. Going to the roots of the stem cell controversy. Bioethics 2002;16:493-507.

2 de Wert G, Mummery C. Human embryonic stem cells: research, ethics and policy. Hum Reprod 2003;18:672-82.

3 Bowring F. Therapeutic and reproductive cloning: a critique. Soc Sci Med 2004:58:401-9.

4 Cibelli JB, Grant KA, Chapman KB, et al. Parthenogenetic stem cells in nonhuman primates. Science 2002;295:819.

5 Vrana KE, Hipp JD, Goss AM, et al. Nonhuman primate parthenogenetic stem cells. Proc Natl Acad Sci U S A 2003;100:11911-16.

6 Rogers NT, Hobson E, Pickering S, et al. Phospholipase Czeta causes Ca2+ oscillations and parthenogenetic activation of human oocytes. Reproduction 2004; 128:697-702

7 Lin H, Lei J, Wininger D, et al. Multilineage potential of homozygous stem cells derived from metaphase II oocytes. Stem Cells 2003;21:152-61.

8 Holden C. Stem cell research. Primate parthenotes yield stem cells. Science 2002;295:779-80.

9 Loeb J. On the nature of the process of fertilization and the artificial production of normal larvae (plutei) from unfertilized eggs of the sea urchin. Am J Physiol $1899 ; 3: 135-8$.

10 Engelhardt HT. Bioethics in the third millennium: some critical anticipations. Kennedy Inst Ethics J 1999;9:225-43.

11 Turner L. Zones of consensus and zones of conflict: questioning the "common morality" presumption in bioethics. Kennedy Inst Ethics J 2003;13:193-218.

12 Turner L. Bioethics in pluralistic societies. Med Health Care Philos 2004;7:201-8.

13 Müller I. Die Wandlung embryologischer Forschung von der deskriptiven zur experimentellen Phase unter dem Einfluß der Zoologischen Station in Neapel. Medizinhist J 1975;10:191-218.

14 Müller I. The impact of the Zoological Station in Naples on developmental physiology. Int J Dev Biol 1996;40:103-11.

15 Herbst CA. Jacques Loeb. Ein kurzer Überblick über sein Lebenswerk. Naturwissenschaften 1924;12:397-406.

16 Pauly PJ. Controlling life: Jacques Loeb and the engineering ideal in biology. New York: Oxford University Press, 1987.

17 Turney J. Life in the laboratory: public responses to experimental biology. Public Underst Sci 1995:4:153-76.

18 Turney J. Creating life in the laboratory. Frankenstein's footsteps. Science, genetics and popular culture. New Haven, London: Yale University Press, 1998:64-90.

19 Loeb J. Mechanistic science and metaphysical romance. The Yale Review 1915:4:766-85.

20 Loeb J. Letter. Jacques Loeb to Ernst Mach 02.11.1894. Ernst Mach papers. Deutsches Museum, Archive NL174/1959.

21 Loeb J. The dynamics of living matter. New York: Columbia University Press, 1906.

22 Loeb J. Das Leben. In: Bloßfeld W, eds. Der erste internationale MonistenKongreß in Hamburg vom 8-11 September 1911. Leipzig: Alfred Kröner Verlag, 1912:77-93.

23 Loeb J. The mechanistic conception of life. Chicago: University of Chicago Press, 1912.

24 Rasmussen CT, Tilman R. Jacques Loeb: his science and social activism and their philosophical foundations. Philadelphia: American Philosophical Society, 1998, 11-37, 65-91.

25 Holden C, Vogel G. Cell biology: a technical fix for an ethical bind? Science 2004;306:2174-6.

26 Fleck L. Genesis and development of a scientific fact. Chicago: Chicago University Press, 1979 (1935)).

27 Latour B. Pandora's hope: essays on the reality of science studies. Cambridge, MA: Harvard University Press, 1999.

28 Gilbert DM. The future of human embryonic stem cell research: addressing ethical conflict with responsible scientific research. Med Sci Monit 2004; 10:RA99-103. 